\title{
Searching Ground Water Sources by Geoelectric Method for Tourism Developmentin Taman Harmoni Bali Bukit Asah Bugbug Karangasemregency, Bali Propince
}

\author{
I Nengah Simpen ${ }^{1 *}$, I Wayan Redana ${ }^{2}$
}

\author{
${ }^{1}$ Physics Department, Mathematical and Science Faculty, Udayana University, Jl. Raya Kampus UNUD, Bukit Jimbaran, \\ Kuta Selatan, Badung, Bali Indonesia 80361 \\ ${ }^{2}$ Civil Engineering Department, Engineering Faculty, Udayana University, Jl. Raya Kampus UNUD, Bukit Jimbaran, Kuta \\ Selatan, Badung, Bali Indonesia 80361 \\ *Corresponding author: simpen.nengah@yahoo.com
}

\begin{abstract}
Taman Harmoni Bali Bukit Asah (THB-BA) is place located in Bugbug Village, KarangasemRegency, BaliProvince. Geographically located at 8,5005748 ${ }^{\circ} \mathrm{S}$, $115,6004593^{\circ} \mathrm{E}$. This tourism place has a beach, the name is Bias Putihbeach, people call it Virgin beach. The visitor from month to month continue to increase. This place also has a camp with an axotic view. Even though this exotic destination is so exotic, it still has weaknesses, namely the lack of water availability. While this is still riding in a local water supply group, so the water is still very far from enough, especially for camping, visitors in general, and plant maintenance. For this reason, it is necessary to find a solution so that the Taman Harmoni Bali Bukit Asah (THB-BA) can grow rapidly. One method that is often used to find groundwater sources is the geoelectric method. Research on the search for groundwater sources in THB-BA has been carried out from March 2018 to July 2018. The geological state of the study area is mostly in the form of rocky aluviun soils, which makes it difficult for site selection. Based on the surface geological conditions, a survey was carried out near the Bias Putih beach. A good source of water was found at a depth of $22 \mathrm{~m}$. Later drilling, water was found starting at a depth of $9.5 \mathrm{~m}$. Then drilling continues to a depth of $31 \mathrm{~m}$ with a screen starting at a depth of $23 \mathrm{~m}$ because the position of good water is estimated at a depth of $22 \mathrm{~m}$. The existence of this water has also been tested, it turns out that it is true that there is water.
\end{abstract}

Keywords - groundwater, geoelectric method, Taman Harmoni Bali Bukit Asah.

\section{INTRODUCTION}

Taman Harmoni Bali Bukit Asah(THB-BA) is place located in Bugbug Village, KarangasemRegency, BaliProvince. Geographically located at $8,5005748^{\circ} \mathrm{S}$, $115,6004593^{\circ} \mathrm{E}$. Geologically, it is dominated by alluvium rocks(Hadiwidjojo, 1971). This tourist destination also has a beach, the name is Bias Putihbeach, people call it Virgin beach.Thevisitor from month to month continue to increase. This place also has a camp with an axotic view. Even though this exotic destination is so exotic, it still has weaknesses, namely the lack of water availability. While this is still riding in a local water supply group, so the water is still very far from enough, especially for camping, visitors in general, and plant maintenance. For this reason, it is necessary to find a solution so that the Taman Harmoni Bali Bukit Asah (THB-BA) can grow rapidly. One method that is often used to find groundwater sources is the geoelectric method(Simpen, Redana, Pujianiki, \& Umratul, 2017; Adi Susilo, Sunaryo, \& Fitriah, 2018).

The geoelectric method is one of the geophysical methods that works based on physical parameters in the form of rock resistivity. In principle, the electric current is injected into the soil and then the potential difference is measured(Sudha, Israil, Mittal, \&Rai, 2009; Adi Susilo et al., 2018). Based on the magnitude of the injected current, the potential difference caused and the distance between electrodes, it can be calculated the resistivity ( $\rho$ ) of the rock at the measurement site(Looke, 2000). Geoelectric methods have long been used for mineral exploration, determining rock structures and looking for aquifer structures and even for searching the distribution of leachate pollutants(A. Susilo et al., 2017; Telford, Geldart, \& Sheriff, 1990). The use of geoelectric to find groundwater sources is very satisfying. Thus in this study the search for groundwater sources for the development of the Taman Harmoni Bali Bukit Asah tourism object uses the geoelectric method. The problems that can be raised in this study are: where is the best position of groundwater 
sources based on geoelectricdata for the development of Taman Harmoni Bali Bukit Asah? The purpose of this study was to find the best position of groundwater sources based on geoelectric data for the development of Taman Harmoni Bali Bukit Asah.

\section{RESEARCH METHOD}

\subsection{Place and time of research}

The research was conducted at the Taman Harmoni Bali Bukit Asah in Bugbug Village, Karangasem Regency, Bali Province. Geographically located at around $8,5005748^{\circ} \mathrm{S}, 115,6004593^{\circ} \mathrm{E}$. The location of the research can be seen in Figure 1. Bukit Asah geologically is a hilly area with rocky alluvium soil, so it is rather difficult in choosing a location, but there are also areas with low parts. Based on the surface geological conditions, a survey was carried out near the Bias Putihbeach. In this low area geologically dominated by alluvium(Hadiwidjojo, 1971), with the hope that if the water has been obtained, later the water can be raised with a pumping system. Research has been conducted from March 2018 to July 2018.

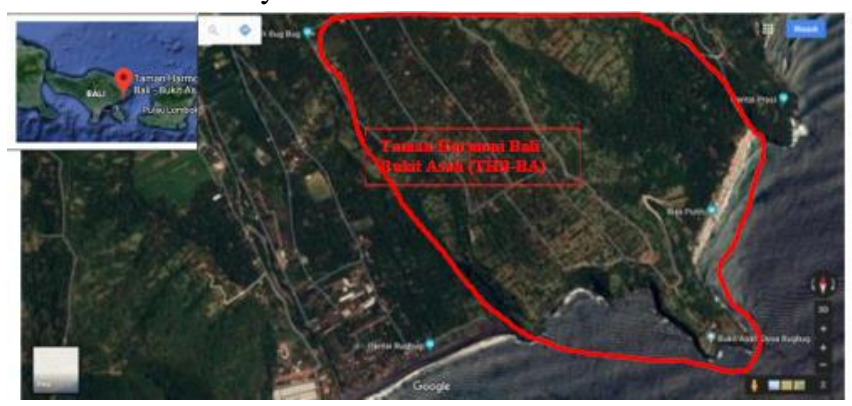

Basic map: https://www.google.com/maps/@-

$\underline{8.5005748,115.6004593,1462 \mathrm{~m} / \text { data }=! 3 \mathrm{ml} ! 1 \mathrm{e} 3 ! 5 \mathrm{~m}}$

$\underline{1 ! 1 e 1}$

Fig.1: Taman Harmoni Bali Bukit Asah (THB-BA) Area

\subsection{Data Collecting Method}

Data is measured by geoelectric method, so the instrument needed is a set of Skill Pro geoelectric devices. Tool sets consist of electrodes, connecting cables, alligator-clamped cables, batteries, hammers, meters, compasses, laptops. To prove the existence of water, drilling is done, the instruments needed is a set of drilling tools. The equipment includes drill bits, water and clay. Measurements were made in areas that were estimated to have a flow of aquifers. The measurement stages are as follows:

a. Make a measurement line.

b. Installation of electrodes

c. Connecting electrodes with resistivity.

d. Take measurements.

Measurements begins by making five measurement lines. The measurement lines is shown in Figure 2.
Electrodes are installed at this linesby a distance between $4.75 \mathrm{~m}$ electrodes. There are 48 electrodes, so the line length becomes $47 \times 4.75 \mathrm{~m}=223.25 \mathrm{~m}$. The electrodes are then connected to the resistivimeter, finally a measurement is did. The magnitude measured is in the form of the magnitude of the injected current and the potential difference caused. This research uses Werner's configuration. The Skill Pro geoelectric tool set can directly record the magnitude of the current and the magnitude of the potential difference in the measurement results.

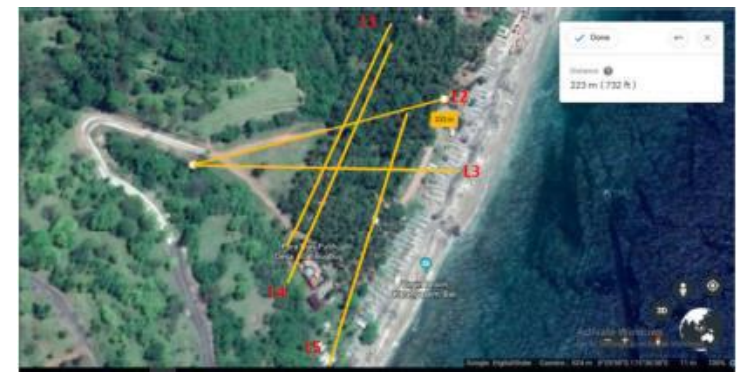

Basic Map:https://earth.google.com/web/@ $\underline{8.50069798,115.61014835,12.74004927 \mathrm{a}, 511.6141234 \mathrm{~d},}$

$35 \mathrm{y},-0 \mathrm{~h}, 0 \mathrm{t}, 0 \mathrm{r}$

$\mathrm{L}_{1 . .5}$ : measurement lines

\section{Fig.2: Measurement lines}

\subsection{Data Analysis Method}

The measurement results are in the form of current magnitude and potential difference as well as the relationship between the two quantities that produce apparent resistivity analyzed by the Res 2 dinv program. The analys is output is in the form of contour cross section resistivity, this contour is interpreted. After the position of the aquifer is obtained, proceed with drilling and installation of a test pump to prove that there is water in the area. If there are water, that means the data analys is is correct.

\section{RESULT AND DISCUSION}

\subsection{Research data}

Data retrieval is done on the measurement lines. Photographs of measurement activities can be seen in the Figure 3.

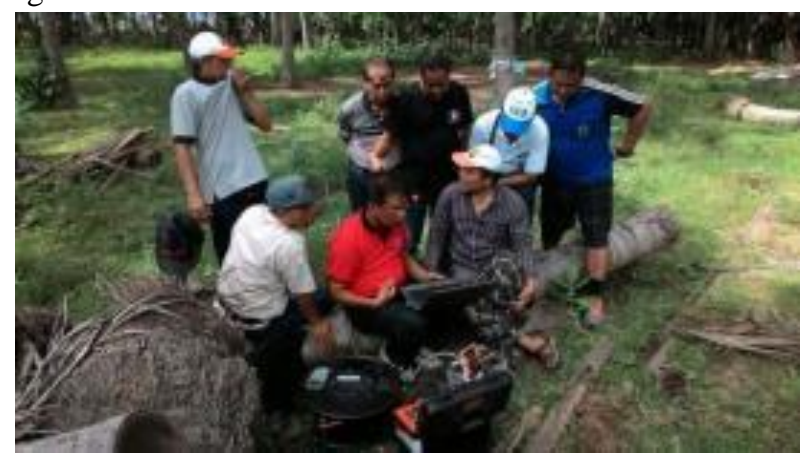

Fig.3: Geoelectric Data Measurement 
The data obtained was analyzed by the Res2dinv program so that the real resistivity values were obtained for each point in the cross section. The resistivity contours of each cross section can be seen in Figure 4-Figure 8.

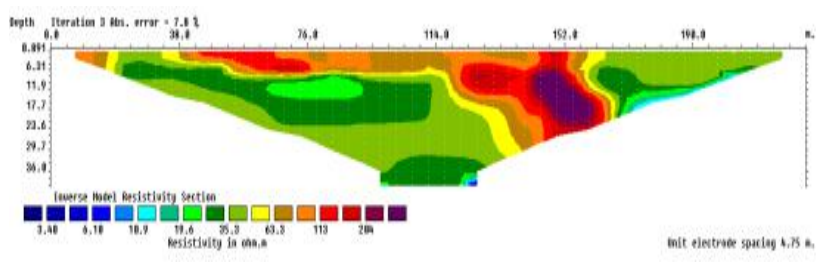

Fig.4: Resistivity Section Contour Line 2

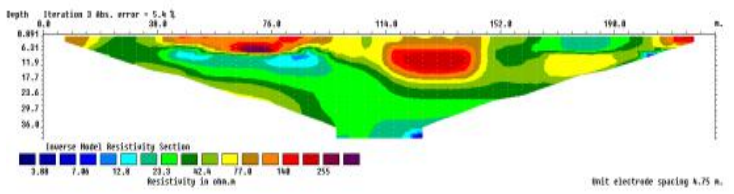

Fig.5: Resistivity Section Contour Line 3

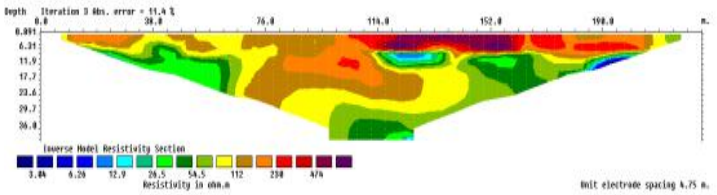

Fig.6: Resistivity Section Contour Line 1

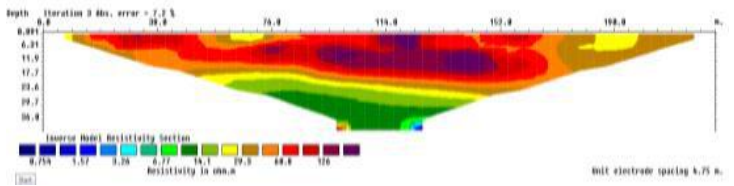

Fig.7: Resistivity Section Contour Line 4

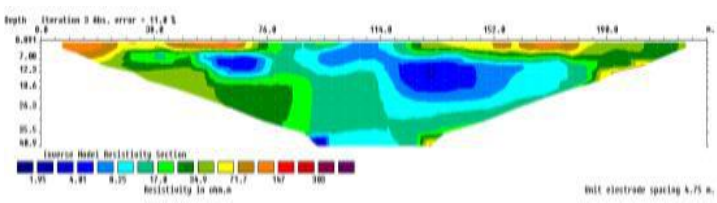

Fig.8: Resistivity Section Contour Line 5

\subsection{Interpretation of Geoelectric Data}

Based on the contour resistivity of each line, it can be said that in each section there are areas that have very small resistivity with resistivity values between 5-50 $\Omega$.m which are thought to be aquifers. Among the five lines, line 3 is the most likely to be drilling at position $99.75 \mathrm{~m}$, because at this point the water is collected, so that on line 3 drilling is carried out.

\subsection{Proofing of the existence of a water source}

Based on the results of drilling on line 3 at point $99.75 \mathrm{~m}$ (Figure 9), aquifers were obtained at a depth of $12 \mathrm{~m}$, but according to geoelectric data, good water was estimated at a depth of $22 \mathrm{~m}$, so drilling continued to a depth of $31 \mathrm{~m}$. To avoid the presence of unfavorable water contamination, the cassing screen is made from a depth of $23 \mathrm{~m}$. The casing uses paralon pipe AW type 5 '.
After completion of drilling, a pilot installation of the pump is also carried out to ensure that there is actually water in the well. It turns out there is water and can be taken (Figure 10). The well data obtained is a surface depth of $9.47 \mathrm{~m}$ and a well depth of $26.92 \mathrm{~m}$.

The presence of water in the well indicates that the groundwater source has been found. Furthermore, this water can be used for tourism development in the Taman Harmoni Bali Bukit Asah.

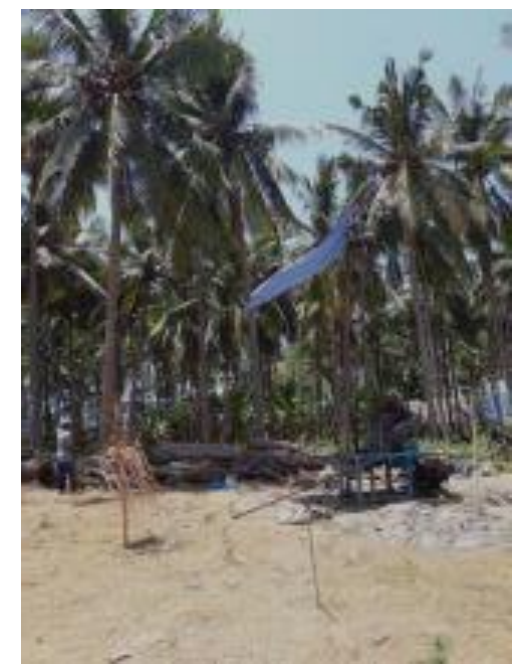

Fig.9: Drilling on Line 3 Point 99.75

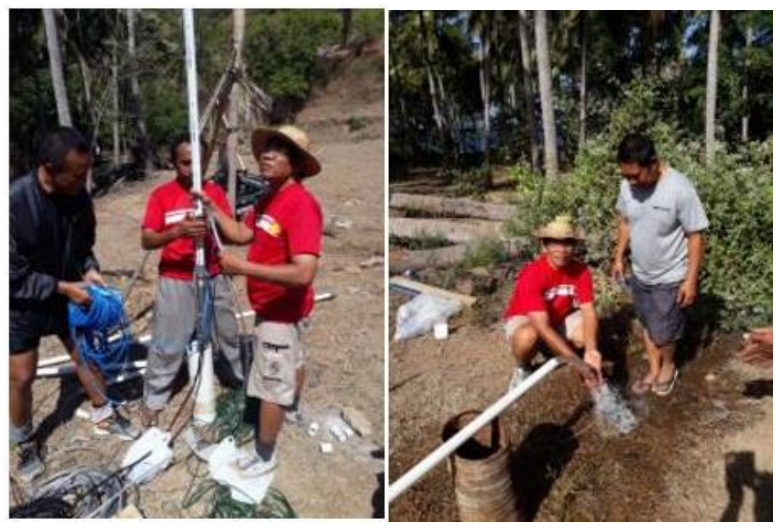

Fig.10: Testing of Pump Installation in Drilling Well

\section{CONCLUSION}

This study uses five lines measurement. From the five lines, there are visible aquifer grooves. Some of these aquifer grooves are spread, some are gathering. The collecting groove will provide more quantity of water, so the location that is most suitable to be explored as a source of ground water is line 3 at position $99.75 \mathrm{~m}$.

\section{REFERENCES}

[1] Hadiwidjojo (Cartographer). (1971). Peta Geologi Pulau Bali.

[2] Looke, M. H. (2000). Electrical imaging surveys for environmental and engineering studies England: Birmingham University. 
[3] Simpen, I. N., Redana, I. W., Pujianiki, N. N., \& Umratul, I. (2017). Aquifers Selection to Aid Geoelectrical Methods on Drilled Well Building near the Beach. International Journal of Physical Sciences and Engineering, 1(3), 41-50. doi: http://dx.doi.org/10.21744/ijpse.v1i3.66

[4] Sudha, K., Israil, M., Mittal, S., \& Rai, J. (2009). Soil characterization using electrical resistivity tomography and geotechnical investigations. Journal of Applied Geophysics, 67 (1), 74-79.

[5] Susilo, A., Sunaryo, \& Fitriah, F. (2018). Groundwater Investigation Using Resistivity Method and Drilling for Drought Mitigation in Tulungagung, Indonesia. International Journal of GEOMATE, 15(47), 124-131.

[6] Susilo, A., Sunaryo, T., A., Sutanhaji, Fitriah, F., \& Hasan, M. F. R. (2017). Identification of Underground River Flow in Karst Area Using Geoelectric and Self-Potential Methods in Druju Region, Southern Malang, Indonesia. International Journal of Applied Engineering Research, 12(12), 10731-10738.

[7] Telford, W. M., Geldart, L. P., \& Sheriff, R. E. (1990). Applied Geophysics. USA: Cambridge University Press. 